\title{
Employees' Perception of Performance Appraisal System: A Case Study
}

\author{
Francis O. Boachie-Mensah (Corresponding author) \\ School of Business, University of Cape Coast \\ Cape Coast, Ghana
}

Tel: 233-332-137-870_E-mail: fbmens2002@yahoo.co.uk

Peter Awini Seidu

School of Business Studies, Takoradi Polytechnic

Takoradi, Ghana

Tel: 233-243-322-945_E-mail: peter.awini@yahoo.com

\author{
Received: September 22, 2011 \\ Accepted: October 11, 2011 \\ Published: January 16, 2012 \\ doi:10.5539/ijbm.v7n2p73 \\ URL: http://dx.doi.org/10.5539/ijbm.v7n2p73
}

\begin{abstract}
Performance appraisals are essential for effective evaluation and management of staff. Since perceptions influence people's judgement and attitudes towards particular phenomena, it could be expected that the staff of an educational institution might hold diverse opinions about the performance appraisal system in the institution. This study focused on employees' perceptions of performance appraisal biases or errors, and examined the implications for developing and implementing an effective appraisal system in a polytechnic in Takoradi, Ghana. The study also sought to identify pragmatic ways to ameliorate any appraisal biases that may be present in the institution's appraisal system. Data was collected from 140 employees of the institution, which included both academic and administrative staff who had worked in the institution for at least two consecutive years, and whose work had been appraised previously. A content validated semi-structured interview schedule was used to interview the respondents. The data collected was analysed, using descriptive statistics, in order to address the research questions. The results of the study indicate that employees of the institution perceive that the performance appraisal system of the institution is affected by subjectivity, and is influenced by some major errors. The findings have serious managerial implications for training, motivation and provision of resources for effective performance appraisal. A major limitation of the study is that, due to financial constraints, it was conducted in only one institution. Therefore, the findings may not be described as a reflection of the general state of affairs in the other educational institutions in the country.
\end{abstract}

Keywords: Appraisal error, Attribution, Perception, Performance appraisal

\section{Introduction}

In today's competitive business world, it is understood that organisations can only compete with their rivals by innovating, and organisations can be innovative by managing their human resources well. The human resource system can become more effective by having a valid and accurate appraisal system used for rating performances of employees (Armstrong, 2003; Bohlander \& Snell, 2004). Unfortunately, the number of organisations using an effective performance appraisal system (PAS) is limited (Hennessey \& Bernadin, 2003).

Perceptions of employees about the targets, outcomes and uses of performance appraisal (PA) results would be beneficial depending on a number of factors. For example, employees are more likely to be receptive and supportive of a given PA programme if they perceive the process as a useful source of feedback which helps to improve their performance (Mullins, 2007). Employees are likely to embrace and contribute meaningfully to a given PA scheme if they perceive it as an opportunity for promotion, and as an avenue for personal development opportunities, a chance to be visible and demonstrate skills and abilities, and an opportunity to network with others in the organisation. On the other hand, if employees perceive PA as an unreasonable attempt by management to exercise closer supervision and control over tasks they (employees) perform, various reactions may result. PA will be effective if the appraisal process is clearly explained to, and agreed by the people 
involved (Anthony et al., 1999). Without adequate explanation or consultation, PA could turn counterproductive. In addition, staff motivation, attitude and behaviour development, communicating and aligning individual and organisational aims, and fostering positive relationships between management and staff are essential for successful appraisal (Armstrong, 2003).

In order to obtain accurate PA information, raters must provide objective and unbiased ratings of employees. Due to difficulty in developing an accurate performance checklist, managers' subjective opinions are frequently called for. Many organisations use some combination of subjective and objective assessment for actual PA. Yet, there are numerous problems in actual assessment of employee performance (Corbett \& Kenny, 2001). The existence of such problems suggests that PAS may be fraught with biases or errors, resulting in compromised evaluations of employees' accomplishments and capabilities. And the PAS of the institution of study might not be an exception. For a PAS to be perceived as fair, it must be free of bias. It is known that appraisal errors can harm perceptions of pay system fairness by confusing the relationship between true performance differences (Miceli et al., 1991). The importance of effective PA in organisations cannot be overemphasised as appraisals help develop individuals, improve organisational performance and feed into business planning. An understanding of the phenomenon, therefore, in every sector of human endeavour is imperative. This recognition has raised interest in studying people's perceptions of the quality of PA in organisations (educational institutions inclusive).

There, however, seems to be a paucity of credible data on the quality of PA in Ghana's educational sector. The Ghanaian situation is relatively unexamined in genre academic literature. This makes it difficult to fashion an appropriate management intervention to address any existing problem, because the exact dimensions of the challenge and its causes are not known. It is against this backdrop that this study was undertaken. It sought to assess the level of perceived PA biases in the educational sector in Ghana by analysing employees' perceptions of PA in one of the ten polytechnics in the country. The study sought to examine PA from the perspective of employees' perceptions of errors with the view to gathering and analysing information that could assist in development of innovative approaches to achieve both individual and corporate goals. Findings of the study would help fill the gap in extant literature. The findings would also provide useful insights and guidelines for enhancing the quality of PA in organisations.

\section{Literature Review}

\subsection{The process and purpose of performance appraisal}

Studies show that there are many approaches for evaluating employee behaviour and performance with respect to job tasks and/or organisational culture. As a result, various applications of PA have left many managers in a state of confusion and frustration with the employee evaluation process (Gurbuz \& Dikmenli, 2007). This situation seems to negatively impact the popularity of appraisal systems in many organisations. Most people support the concept and purpose of PA, in spite of their concerns about the process and application of appraisal outcomes by managers (Grote, 1996). The biggest complaint from managers is that they are not given sufficient guidelines to assess people; and the biggest complaint from employees is that the process is not equitable and fair. PA concentrates much in assessing past behaviours of employees, a situation some managers exploit to victimise unfavoured employees (Bersin, 2008).

The appraisal process has been categorised into: (1) Establishing job criteria and appraisal standards; (2) Timing of appraisal; (3) Selection of appraisers and (4) Providing feedback (Scullen et al., 2003). Early PA processes were fairly simple, and involved ranking and comparing individuals with other people (Milkovich \& Boudreau 1997). However, these early person-based appraisal systems were fraught with problems. As a result, a transition to job-related performance assessments continues to occur. Thus, PA is being modified from being person-focused to behaviour-oriented, with emphasis on those tasks or behaviours associated with the performance of a particular job (Wellbourne etb al., 1998).

Regarding the purpose of PA, Cleveland et al. (1989) describe four types of uses of performance appraisal: between person, within person, system maintenance and documentation. Between person uses are what have been referred to as administrative purposes, consisting of recognition of individuals' performance to make decisions regarding salary administration, promotions, retention, termination, layoffs and so forth. Within person uses are those identified in Management by Objectives (MBO), such as feedback on performance strengths and weaknesses to identify training needs and determine assignments and transfers. PA also helps in organisational goals, which are referred to as system maintenance uses. Finally, documentation purposes are to meet the legal requirements by documenting HR decisions and conducting validation research on the PA tools. Some organisations are attempting to meet all of these goals simultaneously while they continue to use tools that were designed for one type of purpose (Wiese \& Buckley, 1998). Jawahar and Williams's (1997) findings suggest that 
ratings collected for administrative purposes are more lenient than ratings for research or developmental purposes. Although rating scale formats, training and other technical qualities of PA influence the quality of ratings, the quality of PA is also strongly affected by the administrative context in which they are used (Murphy \& Cleveland, 1995). Effective managers recognise PAS as a tool for managing, rather than a tool for measuring subordinates. Such managers use PA to motivate, direct and develop subordinates, and to maximise access to important resources in the organisation to improve productivity.

\subsection{Rater issues}

Researchers have shown considerable interest in variables related to the individual doing the appraisal (Lefkowitz, 2000; Levy \& Williams, 2004; Robbins \& DeNisi, 1998). One of the most studied rater variables is rater affect (Levy \& Williams, 2004). A general definition of affect involves liking or positive regard for one's subordinate (Lefkowitz, 2000). Forgas and George's (2001) study suggests that affective states impact on judgements and behaviours and, in particular, affect or mood plays a large role when tasks require a degree of cognitive processing. In PA, raters in good mood tend to recall more positive information from memory and appraise performance positively (Sinclair, 1988). Affective regard is related to frequently higher appraisal ratings, less inclination to punish subordinates, better supervisor-subordinate relationships, greater halo, and less accuracy (.Lefkowitz, 2000). Antonioni and Park (2001) found that affect was more strongly related to rating leniency in upward and peer ratings than it was in traditional top-down ratings. This effect was stronger when raters had observational time with their subordinates.

A second broad area related to raters is the motivation of the rater. Traditionally, researchers seemed to assume that raters were motivated to rate accurately, and that the problems with the appraisal process involved cognitive processing errors and complexities (Levy \& Williams, 2004). This position has, however, been questioned, leading to attempts to identify and understand other elements of raters' motivation and how such motivation affects the appraisal process. The issues involved include individual differences and the rating purpose on rating leniency. Most practitioners report overwhelming leniency on the part of their raters, and this rating elevation has been found in empirical papers as well as surveys of organisations (Murphy \& Cleveland, 1995; Villanova et al., 1993; Bernadin et al., 2000).

The role of attribution in the PA process has also attracted recent research attention on how the attribution that raters make of ratees' behaviours affect their motivation to rate or their actual rating (Struthers et al., 1998). Raters consider ratees' behaviours and their reputations when drawing attributional inferences and deciding on appropriate rewards (Johnson et al., 2002). This implies that attributional processing is an important element of the rating process, and these attributions, in part, determine raters' reactions and ratings. Another aspect of rater motivation has to do with rater accountability (Frink \& Ferris, 1998). Klimoski and Inks (1990) posit that raters distort appraisal ratings more when they are to be held accountable to the ratee for those ratings. They emphasise that accountability can result in distortions of performance ratings. This view is confirmed by other research findings (Mero et al., 2003; Shore \& Tashchian, 2002). There have also been calls from practitioners to use accountability as a means of improving the accuracy of appraisal ratings, increasing acceptance of the appraisal system, and making the HR system more efficient (Digh, 1998).

\subsection{Ratee issues}

A second major focus of PA research relates to the role of PA in ratee motivation and ratee reactions to PA processes. The research focusing on motivation is generally categorised as being about either (1) the links between performance ratings and rewards or (2) those elements of the PA process which increase ratees' motivation, such as participation (Levy \& Williams, 2004; Goss, 2001; Campbell et al., 1998). One theme of some recent work is that although merit pay systems sound like a good idea, there is very little evidence indicating that they are at all successful (Goss, 2001). In spite of its intuitive appeal and theoretical support, merit pay plans seldom reach their objectives (Campbell et al., 1998). Mani (2002) argues that while pay is an important motivator along with recognition, work enjoyment, and self-motivation, very few organisations actually link the PAS to pay or compensation in any clear, tangible way. Starcher (1996) contends that how well employees perform is much more a function of the situational constraints they experience than their own skills or motivation. But Levy and Williams (1998) argue that these situational constraints are not so important to exclude social or motivational factors that have been quite clearly linked to employee satisfaction and productivity over the years.

Roberts (2003) identified the significance of participation in the PA process as an antecedent of ratees' work motivation. The author suggests that participation is simply essential to any fair and ethical appraisal system. Pettijohn et al, (2001) identify participation and perceptions of fairness as integral to employees' perceptions of job satisfaction and organisational commitment. They conclude that PAS can be used to actually improve 
employees' levels of job satisfaction, organisational commitment, and work motivation. Roberts and Reed (1996) submit that participation, goals, and feedback impact on appraisal acceptance, which affects appraisal satisfaction and eventually employee motivation and productivity.

Ratee reactions to PA has been categorised into: (1) reactions to the appraisal process, (2) reactions to the appraisal structure or format, and (3) reactions to multi-source appraisal or feedback (Levy \& Williams, 2004). Regarding reactions to the appraisal process, Keeping and Levy (2000) argue that perhaps the best criterion to use in evaluating PAS is the reactions of ratees. They claim that an appraisal system will be ineffective if ratees (and raters) do not see it as fair, useful, valid, accurate, etc. Measuring appraisal effectiveness involves, among other things, assessing perceptions of or actual rater errors and biases, rating accuracy and reactions of raters and ratees about the PAS in place (Keeping \& Levy (2000). Folger et al., (1992) identify three elements that must be present to achieve higher perceptions of fairness: adequate notice, fair hearing, and judgment based on evidence. In general, both raters and ratees respond more favourably to fair performance appraisal systems (Brown \& Benson, 2003).

With regard to how individuals react to elements of appraisal structure or methodology, Tziner and Kopelman (2002) found that both raters and ratees responded more favourably to behaviour observation scales (BOS) than they did to other scales, such as graphic rating scales or Behaviourally Achored Rating Scales (BARS). The BARS is generally not well received by raters and ratees, and consistently ranks below the other ratings formats. The value of BOS is that it allows the appraiser to play the role of observer rather than of judge. In this way, they may more easily provide constructive feedback to the employee (Tziner \& Kopelman, 2002). DeNisi and Peters (1996) also examined the role of diary-keeping, and they found that raters react more favourably to PA systems that employ diaries even though in many instances it is more work for them. Raters are better able to recall performance information and are better able to discriminate among employees.

Despite the widespread use of the aforementioned methods, there are dissatisfactions and problems with the feedback systems associated with single source PA (Gurbuz \& Dikmenli, 2007). In response to the concerns raised, considerable emphasis has been placed on developing multi-source feedback systems. It is useful to implement a variety of the appraisal methods simultaneously in an organisation to a wide range of job-performance information for effective decision-making. This gives credence to the use of 360-degree appraisal (Schuler, 1995; Lepsinger \& Lucia (1998; Hurley, 1998). Regarding participants' reactions to multi-source feedback, Waldman and Bowen (1998) propose that factors such as organisational culture, credibility of raters, high rates of participation, and anonymity of ratings are likely to influence its acceptance. Williams and Lueke (1999) also emphasise that knowledge of and experience with the multi-source system as well as social support play an important role in multi-source system reactions. A supportive work environment and an individual's self-efficacy are the most important predictors of employees' attitudes towards multi-source feedback and frequency of developmental activities (Maurer et al., 2002). When individuals receive lower than expected ratings, they respond quite negatively and this may influence their response to developmental activities (Brett \& Atwater, 2001). Generally, if participants do not perceive the system to be fair, the feedback to be accurate, or sources to be credible, then they are more likely to ignore and not use the feedback they receive (Facteau et al., 1998).

Regarding whether age, experience, and level of education of employees influence their perception of PAS, Gurbuz and Dikmenli (2007) posit that the less experienced and youthful employees are relatively more anxious during appraisal than the more experienced and older ones. However, employees who undergo PA several times, regardless of their age, accumulate valuable information, knowledge and experience about its process and purpose through the feedback system. This eventually helps reduce their anxiety during subsequent appraisals. In general, both youthful and older employees' perception of PAS does not vary significantly according to their ages. The authors further suggest that highly educated and professionally competent appraisees are generally more co-operative and supportive of PA than those of relatively lower educational and professional competence. However, many factors, including organisational leadership and culture, impact the attitude of most employees towards PA, regardless of their educational or professional standing (Gurbuz \& Dikmenli, 2007).

\subsection{Superior-subordinate relationship issues}

Trust is a key element in managing the supervisor-employee relationship (Patton, 1999; Mayer \& Davis, 1999). Researchers believe that trust issues can limit the effectiveness of PA (Levy \& Williams, 2004; Dirks \& Ferrin, 2001; Hedge \& Teachout, 2000). If ratees have low levels of trust for their supervisor, they may be less satisfied with the appraisal and may not readily accept feedback from that source. Mani's (2002) study suggests that trust in supervisors is important for determining satisfaction with the appraisal system. In examining factors that influence trust within the PA process, Korsgaad and Roberson (1995) submit that when employees are given assertiveness training and opportunity to self-appraise, they report greater trust in the manager and more positive 
attitude towards the appraisal. According to Mayer and Davis (1999), when a PAS is perceived as accurate and high in instrumentality employees report higher levels of trust for management.

Another leader-member relationship issue is the impact of leader gender on performance ratings. Varma and Stroh (2001) propose that same-sex leader-member relationship would result in greater liking for subordinates. This, in turn, would result in higher leader-member exchange relationships (Duarte et al, 1994). As to whether or not female and male managers rate performance differently, Furnham and Stringfield (2001) posit that male employees receive lower ratings than female employees. Female managers, as compared to male managers, rate male employees lower than female employees. This seems to suggest potential rating bias due to gender.

\subsection{Group dynamics and appraisal}

There has been a growing concern about other multiple, complex relationships that impact on the appraisal process. There has been focus on issues revolving around group, team, or workforce composition, which have been categorised into: (1) politics and impression management, (2) work group or team processes, and (3) the feedback environment or culture experienced by organisational employees. Kozlowski et al. (1998) contend that PA is a ripe situation for those involved to play political games through several approaches, including rater distortion of ratings or ratees' active management of impressions. Similarly, Sims et al. (1987) argue that PA may be used by many raters as a political process for rewarding and punishing subordinates. On the role of impression management in PA, Wayne and Liden (1995) posit that self-focused impression management will lead to less similarity to the subordinate and, thus, lower ratings. Assertive impression management techniques will result in higher performance ratings than defensive impression management techniques (Gendersen \& Tinsley, 1996).

Doing PA in a team-based environment is complicated for various reasons. It is imperative that the appraisal system balances the individual versus the team. Both are important, but emphasising individual or team performance to the exclusion of the other will result in an ineffective system. It is also complicated because the PAS needs to be broad enough to include non-traditional performance criteria such as teamwork or co-operation (.Levy \& Steelman, 1997). Levy and Steelman (1997) considered these complexities in proposing a team-based model for the appraisal system. This model certainly requires adjustments to fit a particular organisation, but the generic model includes multi-source ratings of both individual and team performance, objective measures of individual and team performance as well as measures of teamwork.

Another important element that impacts group dynamics in relation to PA is the feedback environment, otherwise referred to as feedback culture (London \& Smither, 2002). Feedback is an integral component of the PA process in organisations characterized by feedback-oriented culture (London, 2003). A more favourable feedback environment leads to higher levels of commitment and organisational citizenship behaviours. In the view of Steelman et al. (2004), using feedback as a diagnostic tool to identify strengths and weaknesses of supervisors as coaches has great potential for improving the PA process.

\subsection{Errors in performance appraisal}

In practice, there are many possible errors or biases in the PA process. Raters are usually blamed for most of these errors. They affect the objectivity of the appraisal negatively. The most common errors in appraisal are discussed.

One of the most common errors in PA is the halo effect. It is the influence of a rater's general impression on ratings of specific ratee qualities (Solomonson \& Lance, 1997). The rater gives subordinates good grades although their performances are not worthy. Sometimes one prominent characteristic of the subordinate may colour the supervisor's perception of other qualities of the subordinate. This occurs because raters sometimes fail to evaluate the employee's other characteristics separately. From his review of several studies, Lefkowitz (2000) concludes that positive regard for subordinates is often associated with greater halo effect and better interpersonal relationship. Horn effect is the opposite of halo effect. It means that the rater might give poor grade even though the ratee's performance is commendable. Some raters have tendencies to view negatively all behaviours or actions of a subordinate because the superior dislikes a particular behaviour or action of the subordinate (Lefkowitz, 2000).

The leniency error is perhaps the second most common appraisal error (Tziner \& Kopelman, 2002). Some managers are concerned about damaging a good working relationship with a subordinate by giving poor or negative ratings. For this reason, they have the tendency to give ratees higher ratings than they truly deserve. Lenient raters have the tendency to rate subordinates higher just because they do not want to adversely impact the future of the subordinate or risk being perceived as a harsh superior. Management psychologists claim that PA ratings obtained for administrative purposes (such as pay raises or promotions) would be more lenient than ratings meant for feedback or employee development purposes (Jawahar \& Williams, 1997). 
The error of strictness error occurs when raters give unfavourable or poor appraisal regardless of the actual performance level of the ratee. The tight raters set very high evaluation standards. And they might score subordinates' performance below maximum level of the scale. In the view of Tziner and Kopeman (2002), the main reason for this error is that the rater may be uncomfortable that successful ratees may replace them in the future. It is also due to the fact that some raters want to create the impression that they are hard and perfectly placed, and are unwilling to give high ratings even if the ratee's performance is very commendable.

Rather than give extremely poor or good ratings, there is a tendency on the part of some raters to evaluate all ratees as average performers even if actual performances of employees vary. Some raters want to rate employees in the middle of the scale rather than the extremes. According to Dessler (2000), this error (the central tendency error) is mostly committed for two main reasons: when the rater lacks adequate information and knowledge of the employee and, therefore, attempts to reduce the risk of wrong judgment; and when the rater is of the view that appraisal is a waste of time and, as a result, provides average ratings regardless of employee's actual performance value.

Generally, appraisal is conducted once or twice a year in most organisations (Bersin, 2008). The period between one appraisal and the next might be very long for the rater to remember detail information of all relevant performance key points achieved by employees. As a result, some raters only consider the ratee's recent noticeable behaviours or actions on the job regardless of actual performance overall. This is the recency error. Moreover, the ratings may even become more misleading as some ratees attempt to score high ratings by working very hard and demonstrating good performance when appraisal time is approaching (Bersin, 2008).

The contrast error occurs when an employee's evaluation is biased either upward or downward because of another employee's performance, evaluated just previously. Contrast errors are most likely when raters are required to rank employees in order from the best to the poorest. The probability for this error to occur is higher if the rater appraises many employees within a short period (Tziner \& Kopelman, 2002). In other words, an appraisal grade of a ratee may be affected by the grade of another ratee who gets appraised just before him or her.

The similarity effect occurs when raters succumb to the tendency to give better rating to those subordinates similar to themselves in terms of behaviour, personality, or background (Pulakos \& Wexley, 1983). Employees might also contribute to this error when they make efforts to demonstrate that their behaviours, tastes and tendencies match those of the superior, or hide those not matching with the superior's, with the intent to please the superior for more favourable ratings. The effects of "similar to me" error can be powerful, and when the similarity is based on race, religion, or gender, it may result in discrimination (Pulakos \& Wexley, 1983).

Although training for raters may provide solutions to rater errors in some cases, it is ineffective in other instances due to a myriad of factors that distort ratings (Gilbert, 1994). Roberts (2003) argues that four out of ten supervisors believe that employees are to blame for poor performance, when in reality it is poor management practices. To minimise these errors, raters must be fully knowledgeable of the system, and the organisation should provide rater training for managers (Roch \& O’Sullivan, 2003).

\section{Methodology}

The researchers adopted a descriptive survey design for data collection. This design was considered the most appropriate and helpful in determining the perception and attitude of respondents on the variables studied (Gay, 1992; Newman, 2003). The target population comprised academic and administrative staff of the Polytechnic. However, the eligible population of the study included all academic and administrative staff who had worked in the institution for at least two consecutive years. Out of a total of 423 staff, a sample of 140 respondents (82 academic staff and 58 administrative staff) was selected. Due to the need for specific information, a cross-section of the staff was purposively sampled, which comprised employees who had participated in the institution's appraisal process for at least two years. This is because purposive sampling technique allows for the selection of subjects who are more likely to provide the right information for the study (Osuala, 2005). The total number of respondents selected is shown in Table 1.

\section{Insert Table 1 here}

A semi-structured interview schedule was used to elicit data from the respondents. This technique was used in order to reduce interviewer bias and achieve a high degree of consistency in procedure (Sarantakos, 2005). The instrument for the main study was pre-tested at an analogous educational institution. The outcome of the pre-test enabled the researchers to review the final instrument for the study. The researchers and a trained research assistant collected the data for the study between January and February 2009. The data collected were edited, coded and processed with the Statistical Package for Science Solutions (SPSS). 


\section{Findings and discussions}

\subsection{Socio-demographic characteristics of respondents}

Table 2 summarises the frequency distribution of the age of respondents. The results show that the majority of the respondents $(58.6 \%)$ were between the ages of 27 and 36 years. A few of them $(12.9 \%)$ were 26 years and below, and $28.6 \%$ were 37 years and above. This distribution suggests that majority of the employees were relatively youthful. Younger employees of the institution might manifest greater sense of anxiety during appraisal than the older ones. However, Gurbuz and Dikmenli (2007) suggest that youthful as well as older employees' perception of PA generally does not vary significantly according to their ages. This apparently suggests that younger and older employees alike are substantially similar in terms of their perception of PA errors, as well as their commitment and willingness to submit to PA.

\section{Insert Table 2 here}

The results in Table 3 show that majority of the respondents (55\%) possessed a Bachelor's degree or equivalent professional qualification, and $27.1 \%$ were holders of either a college diploma or certificate. Nearly $18 \%$ of them were Master's degree holders. However, none of the respondents had a $\mathrm{PhD}$ qualification. There is a general notion that highly educated and trained people perform tasks within their professional competence. They tend to support established procedures and standards of performance. It is, therefore, not farfetched to state that respondents with higher professional qualifications and advanced academic qualifications might manifest greater co-operation, commitment and willingness to submit to the PAS than their counterparts with relatively lower qualifications. This view is supported by Gurbuz and Dikmenli's (2007) findings. As a developing academic institution, many of the employees required opportunity to improve on their academic and professional credentials so as to contribute more effectively towards attaining organisational goals.

\section{Insert Table 3 here}

It is evident from the results in Table 4 that majority of the respondents $(40.7 \%)$ had worked in the institution for between 7 and 15 years, and a further $30 \%$ for more than 16 years. In effect, most of the respondents $(70.7 \%)$ had worked in the institution for at least 7 years consecutively. This group of employees most certainly might have gone through the PA process several times, and could be considered to have gained greater insight into the system. Therefore, they might be better placed to provide relevant information to facilitate fairer assessment of the PAS. This view is supported by Gurbuz and Dikmenli's (2007) argument that employees who undergo PA several times acquire significant information, knowledge, and experience about its process and purpose through the feedback mechanism.

\section{Insert Table 4 here}

\subsection{Respondents' perception of PA errors, and the magnitude of perceived errors in the PAS}

\subsubsection{Perception of the halo effect}

From the results in Table 5, it can easily be observed that approximately $42 \%$ of the respondents perceived that some of the raters had the tendency to view positively all behaviours of subordinates because the rater liked a particular behaviour of the subordinate. Nearly $35 \%$ of them also thought most of the raters committed this error, while almost $3 \%$ claimed all of the raters committed it. This is perhaps the second most common appraisal error in the institution's appraisal system, according to the results of the study. About $79.3 \%$ of them believed that some or most or all raters manifested this bias during appraisal.

\section{Insert Table 5 here}

The trait-rating or graphic rating scale was used for appraisal of employees' performance in the institution. The halo error is common with the graphic rating scale, especially those that do not include carefully developed descriptions of the employee behaviours being rated. This situation was apparent with the institution's appraisal form. Some of the performance dimensions on the scale were not clearly defined for the rater. These vague performance dimensions would call on the rater to link observed behaviour with the appropriate personality trait, making it prone to rater errors (Cascio, 1991). Rater subjectivity is reduced somewhat when the dimensions on the scale and the scale points are defined (Bernadin \& Beatty, 1984). Due to the presence of raters' positive regard for subordinates, their ability to evaluate the employees' performance characteristics separately was apparently clouded. This situation supports the submission by Lefkowitz (2000) that positive regard is often associated with halo effect and better interpersonal relationship. A major consequence of this error is that ratees are denied the opportunity to meaningfully identify deficiencies in their work performance.

The principal raters in the institution included heads and supervisors of the various Departments or Units, and co-ordinated by the HR section. Furthermore, a Quality Control Unit was in place. Its functions included streamlining the appraisal process to assure procedural fairness, and resolving contentions which arose from 
appraisal outcomes.

\subsubsection{Perception of the horn effect}

The results in Table 6 reveal that about $39 \%$ of the respondents were of the view that some of the raters had the tendency to consider negatively all behaviours of a subordinate, because the rater disliked a particular behaviour of the subordinate. Approximately $32 \%$ of them believed that most of the raters committed this error during appraisal. Meanwhile, about $4 \%$ of them claimed all the raters committed the error.

\section{Insert Table 6 here}

The occurrence of this error might be influenced by unresolved personal disagreements between some raters and ratees. Some aggrieved raters, as the respondents claimed, saw the appraisal as an opportunity to show the supposed "offending" ratee 'where power lies' by giving them poor rating, even if they performed creditably. However, ratees in good relationship with some aggrieved raters received higher ratings even if their performance was unmeritorious. This state of affairs corroborates Sims et al's. (1987) suggestion that PA may be used by many raters as a political tool for rewarding and punishing subordinates. One important danger with this scenario is that high performers who eventually receive lower ratings might become demotivated, and this could result in reduced productivity.

\subsubsection{Perception of the recency error}

It could be observed from Table 7 that about $45 \%$ of the respondents believed some of the raters were influenced by some subordinates' frequent display of behaviours that they (raters) liked when appraisal time was approaching. Also, about $17.1 \%$ of them held the view that most of the raters committed this error when appraising subordinates whom they had insufficient information on their overall work-performance. However, $17.9 \%$ of them believed none of the raters in the institution committed the recency error.

Insert Table 7 here

PA was conducted annually in the institution. This corroborates the assertion by Bersin (2008) that in most organisations the process often tends towards the annual appraisal. Without having the raters routinely document employee accomplishments and failures throughout the whole appraisal period, the raters are forced to recall recent employee behaviour to establish the rating, thereby committing the recency error. Consequently, the appraisal report might not be comprehensive enough to provide useful feedback on the ratee's true performance. Additionally, the ratings might become even more misleading as ratees would strive to achieve higher ratings by improving on their performance only when the appraisal time was close at hand. Needless to say, the eventual appraisal report would not be very useful for quality decision-making.

\subsubsection{Perception of the error of strictness}

From the results in Table 8, nearly 44\% of the respondents perceived that some of the raters had very high rating standards. Almost $18 \%$ of them claimed that most of the raters were the strict type who had the tendency to give low ratings even though the employee's performance might be relatively commendable. Meanwhile, $27 \%$ of them were of the view that none of the raters displayed such tendency. This error occurs apparently due to intrinsic crave of some raters to create the impression that they are perfectly placed, and are unwilling to give high ratings to an appraisee even if the ratee's performance is highly commendable (Tziner \& Kopelman, 2002).

Insert Table 8 here

\subsubsection{Perception of the leniency error}

As the results in Table 9 show, about $42 \%$ of the respondents perceived that some of the appraisers had the tendency to give unusually high ratings to all ratees unless they (ratees) had a clear deficiency, or they (raters) might not want to adversely impact the future of subordinates. Approximately $12 \%$ of them thought most of the raters committed the leniency error. However, nearly $29 \%$ believed none of the raters committed this error. It was the least common appraisal bias, according to the results of the study. This is not in accord with Tziner and Kopelman's (2002) findings which indicate that leniency error is generally the second most common appraisal error in organisations. Majority (58.5\%) of the repondents perceived that some or most or all raters committed this error.

\section{Insert Table 9 here}

A major contributory factor for the occurrence of this error, as the respondents claimed, was that raters generally preferred to maintain good working relationship with subordinates to confronting the discomfort and conflict usually associated with communicating poor appraisal results to ratees. This is consistent with Murphy and Cleveland's (1995) submission that raters' motivation to give elevated ratings is driven by their inclination to maintain good working relationship with ratees. A key implication of this error is that the final appraisal results 
may not be useful for developmental purposes, since ratees' performance deficiencies may be concealed.

\subsubsection{Perception of the similarity effect}

The results in Table 10 reveal that approximately $41 \%$ of the respondents believed some raters gave better rating to those subordinates similar to them (raters) in terms of behaviour, personality, or background. About $34 \%$ of them thought that most of the raters committed the similar-to-me error during appraisal, while $5 \%$ claimed all raters committed it. The similarity effect was probably the most common appraisal bias with nearly $81 \%$ of them perceiving that some or most or all raters manifested this bias.

\section{Insert Table 10 here}

\subsection{Respondents' views of importance of PA to their career goals}

The views of respondents about the importance of PA to their individual career goals and development are presented on Table 11. The results indicate that about $44 \%$ of them held the view that PA was important to their individual career goals and development. Additionally, nearly $18 \%$ of them were of the view that PA was highly important to their career objectives and ambitions. In contrast, about $11 \%$ were of the opinion that PA was highly unimportant or simply unimportant to their respective career goals, while about $27 \%$ indicated that it was somewhat important to their career objectives.

\section{Insert Table 11 here}

Explaining their responses, the respondents (11\%) who thought PA was unimportant to their career goals contended that appraisal in the institution was just a formality, and therefore a waste of time. This assertion might be due to lack of knowledge and appreciation of the purpose of PA in general. It could also indicate failure on the part of the institutional authorities to create sufficient awareness and conditions to generate interest in employees for PA. In support of their responses, the majority of respondents $(61.5 \%)$, who believed PA was important to their career ambitions, explained that feedback on appraisals enabled them to meaningfully identify their individual strengths, weaknesses and direction in their job performance. This way, they were better placed to fairly assess their training needs and learning desires, so as to access appropriate guidance, counselling and support for further development.

\subsection{Respondents' views of importance of PA to the objectives of the institution}

From the results in Table 12, about $46 \%$ of the respondents held the view that PA was important to achieving the goals of the institution. About $31 \%$ of them believed it was highly important to appraise the performance of employees as part of the process of attaining success in the institution. Furthermore, about $14 \%$ indicated that PA was somewhat important to the success of the institution, while a minority (about $8 \%$ ) maintained it was highly unimportant or simply unimportant to achieving the goals of the institution.

\section{Insert Table 12 here}

Justifying their responses in favour of the importance of PA to the institution, respondents provided several explanations, which basically bordered on administrative and developmental purposes. Some of the administrative purposes included decisions on promotions, separation, confirmation of appointment, criteria for evaluating the effectiveness of selection and placement. PA also provided information on which basis work scheduling plans, budgeting, and HR planning occurred. It, therefore, helped in formulating policy on allocation of resources to the various units or departments of the institution. For developmental purposes, some respondents acknowledged the importance of PA as a means for identifying skills, knowledge and resource discrepancies in the institution for effective measures to be adopted to rectify the situation. In spite of the arguments in favour of PA, a minority (10.8\%) of the respondents contended that it was typically concerned with the past rather than being forward looking. And it was susceptible to manipulation and bias against "unfavoured" employees, as Bersin (2008) posits.

\subsection{Respondents' commitment to the PAS}

From Table 13, about $36 \%$ of the respondents indicated they were committed to the appraisal system. Nearly $14 \%$ of them confirmed they were very committed to the system. However, almost $29 \%$ of them were either uncommitted or very uncommitted to it.

\section{Insert Table 13 here}

The respondents raised some concerns for this attitude towards the PAS. Employees were not involved in formulation of objectives and criteria for PA. As a result, there was inadequate awareness and lack of understanding of the process, importance and implications of the appraisal system. This echoes the relevance of the suggestion that participation is essential to any fair and ethical appraisal system (Roberts, 2003; Pettijohn et al. (2001). In effect, the respondents were concerned about apparent lack of procedural fairness in terms of 
access to information on the criteria and objectives of the PAS. Appraisees did not receive adequate feedback on appraisal outcomes. This situation affirms Gurbuz and Dikmenli's (2007) findings that there are dissatisfactions and problems with the feedback systems associated with single source PA. There was no rater accountability for their ratings of employees. This means raters were not held answerable for their ratings of employees.

4.6 Respondents' willingness to submit to the PAS

The results in Table 14 reveal that majority (about 57\%) of the respondents were willing or very willing to submit to the PAS. In addition, nearly $21 \%$ of them were somewhat willing to submit to it. However, about $8 \%$ and $14 \%$ were either very unwilling or unwilling to take part in the appraisal process. The reasons advanced by these respondents for their attitude were similar to those expressed earlier by the respondents who were uncommitted to the system. Generally speaking, the respondents' perception of PA errors apparently had minimal adverse effect on their commitment and willingness to submit to the system, since the vast majority (about 77.8\%) of them affirmed their support for it. This reinforces Grote's (1996) assertion that most people support the concept and purpose of PA, in spite of their concerns about its process and application by managers.

Insert Table 14 here

\section{Conclusion and implications}

This study set out to investigate the perception of errors that employees have of the PAS of a polytechnic in Takoradi, Ghana. The results revealed a negative perception that the employees held of the PAS. That the system was affected by subjectivity, and was influenced by some major errors, the most common of which were the similarity and the halo effect biases. There was very little employee involvement in formulating criteria, agreeing performance standards and objectives for the appraisal. Employees were not well informed about the time, process and purpose of PA. In spite of their perception of PA errors, the majority of employees were committed and willing to submit to the process, even though a significant minority thought otherwise. Most employees viewed the system as important to both their individual career goals as well as the objectives of the institution. There was irregular and inadequate feedback on appraisal outcomes to all employees, except in the case of very poor performers. Appraisal was conducted only once in a year, and this created fertile grounds for the occurrence of the recency error.

The study has provided some information on what needs to be changed in order to improve PA of employees in the institution. The findings have serious managerial implications for training, motivation and provision of resources for effective PA. In order to minimise, if not completely eliminate, perceived appraisal errors, as well as establish a more rational system, certain approaches are recommended. Regarding halo effect and leniency error, precise definitions of the job-related behaviours being rated are required. This would help reduce the tendency for appraisers to rely on their individual interpretations. To help reduce the occurrence of recency error, the use of appraisal diary should be considered. This would enable the superior to routinely document employee accomplishments and failures throughout the whole appraisal period. Concerning similarity bias, performance standards must be clearly defined. Additionally, formal training programmes can help reduce subjective errors commonly made during the rating process. Furthermore, institutional authorities should strive to provide regular and adequate feedback to subordinates.

Although the study provides useful insights by demonstrating the importance of effective PA in enhancing performance in an educational institution context, the results need to be interpreted subject to the usual limitation of survey research. In particular, the focus was on perception of employees within the educational sector and in only one institution. Therefore, the findings cannot be described as a reflection of the general state of affairs across other sectors and educational institutions. On the basis of the observations in the study area, future research should focus on case studies of other sectors and organisations in other locations and be directed at other PA errors.

\section{References}

Anthony, W. P., Perrewe, P. L., \& Kacmar, K. M. (1999). Human resource management: A strategic approach. New York: Harcourt Brace.

Antonioni, D., \& Park, H. (2001). The relationship between rater affect and three sources of 360-degree feedback ratings. Journal of Management, 27(4), 479-495. http://dx.doi.org/10.1016/S0149-2063(01)00104-0

Armstrong, M. (2003). A handbook of human resource management practice. London: Kogan Page.

Bernadin, H. J., \& Beatty, R. W. (1984). Performance appraisal: Assessing human behaviour at work. Boston MS: Kent.

Bernadin, H. J., Cooke, D. K., \& Villanova, P. (2000). Conscientiousness and agreeableness as predictors of rating leniency. Journal of Applied Psychology, 85(2), 232-239. 
Bersin, J. (2008). The business case for performance management systems: A handbook for human resource executives and managers. Bersin and Associates Research Reports, 10, 9-22.

Bohlander, G., \& Snell, S. (2004). Managing human resources. Mason, Ohio: South-Western.

Brett, J. F., \& Atwater, L. E. (2001). 360-degree feedback: Accuracy, reactions, and perceptions of usefulness. Journal of Applied Psychology, 86(5), 930-942. http://dx.doi.org/10.1037//0021-9010.86.5.930

Brown, M., \& Benson, J. (2003). Rated to exhaustion? Reactions to performance appraisal processes. Industrial Relations Journal, 34(1), 67-81. http://dx.doi.org/10.1111/1468-2338.00259

Campbell, D. J., Campbell, K. M., \& Chia, H. B. (1998). Merit pay, performance appraisal, and individual motivation: An analysis and alternative. Human Resource Management, 37(2), 131-146. http://dx.doi.org/10.1002/(SICI)1099-050X(199822)37:2<131::AID-HRM4>3.0.CO;2-X

Cascio, W. F. (1991). Applied psychology in personnel management. Englewood Cliffs, NJ: Prentice Hall.

Cleveland, J. N., Murphy, K. R., \& Williams, R. E. (1989). Multiple uses of performance appraisal: Prevalence and correlates. Journal of Applied Psychology, 74(1), 130-135. http://dx.doi.org/10.1037//0021-9010.74.1.130

Corbett, B., \& Kenny, B. (2001). Appraisal and learning in a government agency. The Learning Organisation, 8(1), 21-35. http://dx.doi.org/10.1108/09696470110366516

DeNisi, A. S., \& Peters, L. H. (1996). Organisation of information in memory and the performance appraisal process: Evidence from the field. Journal of Applied Psychology, 81(6), 717-737. http://dx.doi.org/10.1037//0021-9010.81.6.717

Dessler, G. (2000). Human resource management. New Jessey: Prentice Hall.

Digh, P. (1998). The next challenge: holding people accountable. HR Magazine, 43, 19-25.

Dirks, K.T., \& Ferrin, D. L. (2001). The role of trust in organisational settings. Organisation Science, 12(4), 450-467. http://dx.doi.org/10.1287/orsc.12.4.450.10640

Duarte, N. D., Goodson, J. R., \& Klich, N. R. (1994). Effects of dyadic quality and duration on performance appraisal. Academy of Management Journal, 37(3), 499. http://dx.doi.org/10.2307/256698

Facteau, C. L., Facteau, J. D., Schoel, L. C., Russell, J. E. A., \& Poteet, M. L. (1998). Reactions of leaders to 360-degree feedback from subordinates and peers. Leadership Quarterly, 9(4), 427-448. http://dx.doi.org/10.1016/S1048-9843(98)90010-8

Folger, R., Konovsky, M., \& Cropanzano, R. (1992). A due process for performance appraisal. Research in Organisational Behaviour, 15, 129-177.

Forgas, J. P., \& George, J. M. (2001). Affective influences on judgements and behaviour in organisations: An information processing perspective. Organisational Behaviour and Human Decision Processes, 86(1), 3-34. http://dx.doi.org/10.1006/obhd.2001.2971

Frink, D. D., \& Ferris, G. R. (1998). Accountability, impression management and goal-setting in the performance evaluation process. Human Relations, 51(10), 1259-1283. http://dx.doi.org/10.1177/001872679805101003

Furnham A., \& Stringfield, P. (2001). Gender differences in rating reports: female managers are harsher raters, particularly of males. Journal of Managerial Psychology, 16(4), 281-288. http://dx.doi.org/10.1108/02683940110392020

Gay, L. R. (1992). Educational research: Competencies for analysis and application (4 ${ }^{\text {th }}$ ed.). New York: Merril MacMillan.

Gendersen, D. E., \& Tinsey, D. B. (1996). Empirical assessment of impression management biases: The potential for performance appraisal error. Journal of Social Behaviour and Personality, 11(5), 57-77.

Gilbert, C. A. (1994). Performance Appraisal: A Process Analysis of Existing Methods and Trends. [Online] Available: http://home.fuse.net/cgilbert/appraise.htm (April 19, 2006)

Goss, W. (2001). Managing for results - Appraisal and rewards. Journal of Public Administration, 60(1), 3-9. http://dx.doi.org/10.1111/1467-8500.00193

Grote, D. (1996). The complete guide to performance appraisal. New York: American Management Association.

Gurbuz, S., \& Dikmenli, O. (2007). Performance appraisal in public organisations: An empirical study. Magazine of Management Practice, 13(1), 108-138.

Hedge, J. W., \& Teachout, M. S. (2000). Exploring the concept of acceptability as a criterion for evaluating 
performance measures. Group and Organisation Management, 25(1), 22-44. http://dx.doi.org/10.1177/1059601100251003

Hennessey, H. W., \& Bernadin, H. J. (2003). The relationship between performance appraisal criterion specificity and statistical evidence of discrimination. Human Resource Management, 42(2), 143-158. http://dx.doi.org/10.1002/hrm.10073

Hurley, S. (1998). Application of team-based 360-degree feedback systems. Team Performance Management, 4(5), 202-210.

Jawahar, I.M., \& Williams, C. R. (1997). Where all the children are above average: The performance appraisal purpose effect. Personnel Psychology, 50 (4), 905-925. http://dx.doi.org/10.1111/j.1744-6570.1997.tb01487.x

Johnson, D. E., Erez, A., Kiker, D. S., \& Motowidlo, S. J. (2002). Liking and attributions of motives and mediators of the relationships between individuals' reputations, helpful behaviours and raters' reward decisions. Journal of Applied Psychology, 87(4), 808-815. http://dx.doi.org/10.1037//0021-9010.87.4.808

Keeping, L. M., \& Levy, P. E. (2000). Performance appraisal reactions: measurement, modeling, and method bias. Journal of Applied Psychology, 85(5), 708-723. http://dx.doi.org/10.1037//0021-9010.85.5.708

Klimoski, R., \& Inks, L. (1990). Accountability forces in performance appraisal. Organisational Behaviour and Human Decision Processes, 45(2), 194-208. http://dx.doi.org/10.1016/0749-5978(90)90011-W

Kosgaard, M. A., \& Roberson, L. (1995). Procedural justice in performance evaluation: The role of instrumental and non-instrumental voice in performance appraisal decisions. Journal of Management, 21, 657-669.

Kozlowski, S. W. J., Chao, G. T., \& Morrison, R. F. (1998). Games raters play: politics, strategies, and impression management in performance appraisal. In J. W. Smither (Ed.), Performance appraisal: State of the art in practice (pp. 163-205). San Francisco: Jossey-Bass.

Lefkowitz, S. W. (2000). The role interpersonal affective regard in supervisory performance ratings: a literature review and proposed causal model. Journal of Occupational and Organisational Psychology, 73(1), 67-85. http://dx.doi.org/10.1348/096317900166886

Lepsinger, R., \& Lucia, D. (1998). Creating champions for 360-degree feedback. Training and Development, 52, 49-52.

Levy, P. E., \& Steelman, L. A, (1997). Advances in interdisciplinary studies of work teams: Team implementation issues. Greenwich, CT: JAI.

Levy, P. E., \& Williams, J. R. (1998). The role of perceived system knowledge in predicting appraisal reactions, job satisfaction, and organisational commitment. Journal of Organisational Behaviour, 19(1), 53-65. http://dx.doi.org/10.1002/(SICI)1099-1379(199801)19:1<53::AID-JOB826>3.3.CO;2-4

Levy, P. E., \& Williams, J. R. (2004). The social context of performance appraisal: A review and framework for the future. Journal of Management, 30(6), 881-905.

London, M. (2003). Job feedback: Giving, seeking and using feedback for performance improvement. Mahwah, NJ: Lawrence Erlbaum.

London, M., \& Smither, J. W. (2002). Feedback orientation, feedback culture, and the longitudinal performance management process. Human Resource Management Review, 12(1), 80-100. http://dx.doi.org/10.1016/S1053-4822(01)00043-2

Longenecker, C. O. (1997). Why managerial performance appraisals are ineffective: Causes and lessons. Career Development International, 2(5), 221-218. http://dx.doi.org/10.1108/13620439710174606

Mani, B. G. (2002). Performance appraisal systems, productivity, and motivation: A case study. Public Personnel Management, 31(2), 141-159.

Mauer, T. J., Mitchell, D. R. D., \& Barbeite, F. G. (2002). Predictors of attitudes towards a 360-degree feedback system and involvement in post-feedback management development activity. Journal of Occupational and Organisational Psychology, 75(1), 87-107.

Mayer, R. C., \& Davis, J. H. (1999). The effect of performance appraisal on trust for management: A field $\begin{array}{lllll}\text { quasi-experiment. Journal of Applied } & \text { Psychology, } & \text { 84(1), }\end{array}$ http://dx.doi.org/10.1037//0021-9010.84.1.123

Mero, N. P., Motowidlo, S. J., \& Anna, A. L. (2003). Effects of accountability on rating behaviour and rating $\begin{array}{lllll}\text { accuracy. Journal of } & \text { Social } & \text { Psychology, } & 33(12), & \text { 2493-2514. }\end{array}$ http://dx.doi.org/10.1111/j.1559-1816.2003.tb02777.x 
Miceli, M. P., Jung, I., Near, J. P., \& Greenberger, D. B. (1991). Predictors and outcomes of reactions to pay-for-performance plans. Journal of Applied Psychology, 76(4), 508-521. http://dx.doi.org/10.1037//0021-9010.76.4.508

Milkovich, G. M., \& Boudreau, J. W. (1997). Human resource management. Chicago: Irwin.

Mullins, L. J. (2005). Management and organisational behaviour. London: Prentice Hall.

Murphy, K. R., \& Cleveland, J. N. (1995). Understanding performance appraisal: Social, organisational and goal-based perspectives. California: Sage, Thousand Oaks.

Newman, W. L. (2003). Qualitative and quantitative approaches $\left(5^{\text {th }}\right.$ ed.). New York: Pearson Education Inc.

Osuala, E. C. (2005). Introduction to research methodology. Onitsha: African First Publishing Ltd.

Pettijohn, C. E., Pettijohn, L. S., Taylor, A. J., \& Keillor, B. D. (2001). Are performance appraisals a bureaucratic exercise or can they be used to enhance sales-force satisfaction and commitment? Psychology and Marketing, 18(4), 337-364. http://dx.doi.org/10.1002/mar.1011

Pulakos, E. D., \& Wexley, K. N. (1983). The relationship among perceptual similarity, sex, and performance ratings in manager-subordinate dyads. Academy of Management Journal, 26(1), 129-139. http://dx.doi.org/10.2307/256139

Robbins, T. L., \& DeNisi, A. S. (1998). Mood versus interpersonal affect: identifying process and rating distortions in performance appraisal. Journal of Business and Psychology, 12(3), 313-325. http://dx.doi.org/10.1023/A:1025075430010

Roberts, G. E. (2003). Employee appraisal system participation: A technique that works. Public Personnel Management, 32(1), 89.

Roberts, G. E., \& Reed, T. (1996). Performance appraisal participation, goal-setting and feedback: The influence of supervisory style. Review of Public Personnel Administration, 16(4), 29-60. http://dx.doi.org/10.1177/0734371X9601600404

Roch, S. G., \& O'Sullivan, B. J. (2003). Frame of reference rater training issues: Recall, time, and behaviour observation training. International Journal of Training and Development, 7(2), 93-107. http://dx.doi.org/10.1111/1468-2419.00174

Sarantakos, S. (2005). Social research. Australia: MacMillan Press Ltd.

Schuler, R. S. (1995). Managing human resource. Min St. Paul: West Publishing.

Scullen, S. E., Mount, M. K., \& Judge, T. A. (2003). Evidence of the construct validity of developmental ratings of managerial performance. Journal of Applied Psychology, 88(1), 50-66. http://dx.doi.org/10.1037/0021-9010.88.1.50

Shore, T. H., \& Tashchian, A. (2002). Accountability forces in performance appraisal: effects of self-appraisal information, normative information, and task performance. Journal of Business and Psychology, 17(2), 261-274. http://dx.doi.org/10.1023/A:1019689616654

Sims, H. P., Gioia, D. A., \& Longenecker, C. O. (1987). Behind the mask: The politics of employee appraisal. Academy of Management Executive, 1(3), 183-193. http://dx.doi.org/10.5465/AME.1987.4275731

Sinclair, R. C. (1988). Mood, categorization breadth, and performance appraisal: The effects of order of information acquisition and affective state on halo, accuracy, information retrieval, and evaluations. Organisational Behaviour and Human Decision Processes, 42(1), 22-46. http://dx.doi.org/10.1016/0749-5978(88)90018-0

Solomonson, A., L., \& Lance, C. E. (1997). Examination of the relationship between true halo and halo error in performance ratings. Journal of Academic Applied Psychology, 82(5), 665-674. http://dx.doi.org/10.1037//0021-9010.82.5.665

Starcher, R. (1996). Individual performance appraisal systems. Production and Inventory Management Journal, $37(4), 58$.

Steelman, L. A., Levy, P. E., \& Snell, A. F. (2004). The feedback environment scale: Construct definition, measurement, and validation. Educational and Psychological Measurement, 64(1), 165-184. http://dx.doi.org/10.1177/0013164403258440

Struthers, C. W., Weiner, B., \& Allred, K. (1998). Effects of causal attributions on personnel decisions: A social motivation perspective. Basic and Applied Social Psychology, 20(2), 155-166. http://dx.doi.org/10.1207/s15324834basp2002_7 
Tziner, A., \& Kopelman, R. E. (2002). Is there a preferred performance rating format? A non-psychometric perspective. Applied Psychology, 51(3), 479-503. http://dx.doi.org/10.1111/1464-0597.00104

Varma, A., \& Stroh, L. K. (2001). The impact of same sex LMX dyads on performance evaluations. Human Resource Management, 40(4), 309-320. http://dx.doi.org/10.1002/hrm.1021

Villanova, P., Bernadin, H. J., Dahmus, S. A., \& Sims, R. L. (1993). Rater leniency and performance appraisal discomfort. Educational and Psychological Measurement, 53(3), 789-799. http://dx.doi.org/10.1177/0013164493053003023

Waldman, D. A., \& Bowen, D. E. (1998). The acceptability of 360-degree appraisals: A customer-supplier relationship perspective. Human resource management, 37(2), 117-129. http://dx.doi.org/10.1002/(SICI)1099-050X(199822)37:2<117::AID-HRM3>3.0.CO;2-Z

Wayne, S. J., \& Liden, R. C. (1995). Effects of impression management on performance ratings: a longitudinal study. Academy of Management Journal, 38(1), 232-260. http://dx.doi.org/10.2307/256734

Welbourne, T. M., Johnson, D. E., \& Erez, A. (1998). The role-based performance scale: Validity analysis of a theory-based measure. Academy of Management Journal, 41(1), 540-555. http://dx.doi.org/10.2307/256941

Wiese, D. S., \& Buckley, M. R. (1998). The evolution of the performance appraisal process. Journal of Management History, 4(3), 233-249. http://dx.doi.org/10.1108/13552529810231003

Williams, J. R., \& Lueke, S. B. (1999). 360-degree feedback system effectiveness: Test of a model in a field setting. Journal of Quality Management, 4(1), 23-49. http://dx.doi.org/10.1016/S1084-8568(99)80094-7

Table 1. The Sample Size of Respondents in the Polytechnic

\begin{tabular}{|l|c|c|c|c|c|}
\hline $\begin{array}{l}\text { Category of } \\
\text { Respondents }\end{array}$ & $\begin{array}{c}\text { Eligible } \\
\text { Male }\end{array}$ & $\begin{array}{c}\text { Staff } \\
\text { Female }\end{array}$ & $\begin{array}{c}\text { Selected } \\
\text { Male }\end{array}$ & $\begin{array}{c}\text { Staff } \\
\text { Female }\end{array}$ & $\begin{array}{c}\text { No. of Respondents } \\
\text { (Male +Female) }\end{array}$ \\
\hline Academic Staff & 264 & 19 & 75 & 7 & 82 \\
\hline Administrative Staff & 81 & 59 & 37 & 21 & 58 \\
\hline Total & 345 & 78 & 112 & 28 & 140 \\
\hline
\end{tabular}

Source: Survey Data, 2009.

Table 2. Age Distribution of Respondents (Employees)

\begin{tabular}{|l|l|l|l|}
\hline Age (years) & Frequency & Percentage & Cum.\% \\
\hline 26 and below & 18 & 12.9 & 12.9 \\
\hline $27-36$ & 82 & 58.6 & 71.4 \\
\hline 37 and above & 40 & 28.6 & 100.0 \\
\hline Total & 140 & 100.0 & \\
\hline
\end{tabular}

Source: Survey Data, 2009.

$\mathrm{n}=140$

Table 3. Level of Education of Respondents

\begin{tabular}{|l|c|c|}
\hline Level of Education & Frequency & Percentage \\
\hline College Dip. or Certificate & 38 & 27.1 \\
\hline First Degree or Equivalent & 77 & 55.0 \\
\hline Master's Degree & 25 & 17.9 \\
\hline PhD Degree & 0 & 00.0 \\
\hline Total & 140 & 100.0 \\
\hline
\end{tabular}

Source: Survey Data, 2009. $\mathrm{n}=140$

Table 4. Years Worked by Respondents in the Institution

\begin{tabular}{|l|c|c|c|}
\hline No. of Years & Frequency & Percentage & Cum.\% \\
\hline Between 2 and 6 years & 41 & 29.3 & 29.3 \\
\hline Between 7 and 15 years & 57 & 40.7 & 70.0 \\
\hline 16 years and above & 42 & 30.0 & 100.0 \\
\hline Total & 140 & 100.0 & \\
\hline
\end{tabular}

Source: Survey Data, $2009 . \quad \mathrm{n}=140$ 
Table 5. Respondents' Perception of Raters Committing Halo Error

\begin{tabular}{|l|c|c|c|}
\hline Responses & Frequency & Percentage & Cum.\% \\
\hline Don't Know & 21 & 15.0 & 15.0 \\
\hline None & 8 & 5.7 & 20.7 \\
\hline Some & 59 & 42.1 & 62.9 \\
\hline Most & 48 & 34.3 & 97.1 \\
\hline All & 4 & 2.9 & 100.0 \\
\hline Total & 140 & 100.0 & \\
\hline
\end{tabular}

Source: Survey Data, 2009.

$$
\mathrm{n}=140
$$

Table 6. Respondents' Perception of Raters Committing Horn Error

\begin{tabular}{|l|c|c|c|}
\hline Responses & Frequency & Percentage & Cum.\% \\
\hline Don't Know & 24 & 17.1 & 17.1 \\
\hline None & 11 & 7.9 & 25.0 \\
\hline Some & 55 & 39.3 & 64.3 \\
\hline Most & 45 & 32.1 & 96.4 \\
\hline All & 5 & 3.6 & 100.0 \\
\hline Total & 140 & 100.0 & \\
\hline
\end{tabular}

Source: Survey Data, 2009.

$$
\mathrm{n}=140
$$

Table 7. Respondents' Perception of Raters Committing the Recency Error

\begin{tabular}{|l|c|c|c|}
\hline Responses & Frequency & Percentage & Cum.\% \\
\hline Don't Know & 27 & 19.3 & 19.3 \\
\hline None & 24 & 17.9 & 36.4 \\
\hline Some & 63 & 45.0 & 81.4 \\
\hline Most & 24 & 17.1 & 98.6 \\
\hline All & 2 & 1.4 & 100.0 \\
\hline Total & 140 & 100.0 & \\
\hline
\end{tabular}

Source: Survey Data, 2009.

$$
\mathrm{n}=140
$$

Table 8. Respondents' Perception of Raters Committing Strictness Error

\begin{tabular}{|l|c|c|c|}
\hline Responses & Frequency & Percentage & Cum.\% \\
\hline Don't Know & 12 & 8.6 & 8.6 \\
\hline None & 38 & 27.1 & 35.7 \\
\hline Some & 61 & 43.6 & 79.3 \\
\hline Most & 25 & 17.9 & 97.1 \\
\hline All & 4 & 2.9 & 100.0 \\
\hline Total & 140 & 100.0 & \\
\hline
\end{tabular}

Source: Survey Data, 2009.

$$
\mathrm{n}=140
$$

Table 9. Respondents' Perception of Raters Committing Leniency Error

\begin{tabular}{|l|c|c|c|}
\hline Responses & Frequency & Percentage & Cum.\% \\
\hline Don't Know & 18 & 12.9 & 12.9 \\
\hline None & 40 & 28.6 & 41.4 \\
\hline Some & 59 & 42.1 & 83.6 \\
\hline Most & 17 & 12.1 & 95.7 \\
\hline All & 6 & 4.3 & 100.0 \\
\hline Total & 140 & 100.0 & \\
\hline
\end{tabular}

Source: Survey Data, 2009.

$\mathrm{n}=140$ 
Table 10. Respondents' Perception of Raters Committing Similarity Error

\begin{tabular}{|l|c|c|c|}
\hline Responses & Frequency & Percentage & Cum.\% \\
\hline Don't Know & 20 & 14.3 & 14.3 \\
\hline None & 7 & 5.0 & 19.3 \\
\hline Some & 58 & 41.4 & 60.7 \\
\hline Most & 48 & 34.3 & 95.0 \\
\hline All & 7 & 5.0 & 100.0 \\
\hline Total & 140 & 100.0 & \\
\hline
\end{tabular}

Source: Survey Data, 2009.

$\mathrm{n}=140$

Table 11. Respondents' Views of PA Importance to Their Career Goals

\begin{tabular}{|l|c|c|c|}
\hline Responses & Frequency & Percentage & Cum.\% \\
\hline Highly Unimportant & 4 & 2.9 & 2.9 \\
\hline Unimportant & 12 & 8.6 & 11.4 \\
\hline Somewhat Important & 38 & 27.1 & 38.6 \\
\hline Important & 61 & 43.6 & 82.1 \\
\hline Highly Important & 25 & 17.9 & 100.0 \\
\hline Total & 140 & 100.0 & \\
\hline
\end{tabular}

Source: Survey Data, $2009 . \quad \mathrm{n}=140$

Table 12. Respondents' Views of PA Importance to Institution's Objectives

\begin{tabular}{|l|c|c|c|}
\hline Responses & Frequency & Percentage & Cum.\% \\
\hline Highly Unimportant & 4 & 2.9 & 2.9 \\
\hline Unimportant & 7 & 5.0 & 7.9 \\
\hline Somewhat Important & 20 & 14.3 & 22.1 \\
\hline Important & 65 & 46.4 & 68.6 \\
\hline Highly Important & 44 & 31.4 & 100.0 \\
\hline Total & 140 & 100.0 & \\
\hline
\end{tabular}

Source: Survey Data, $2009 . \quad \mathrm{n}=140$

Table 13. Respondents' Level of Commitment to the PAS

\begin{tabular}{|l|c|c|c|}
\hline Responses & Frequency & Percentage & Cum.\% \\
\hline Very Uncommitted & 18 & 12.9 & 12.9 \\
\hline Uncommitted & 22 & 15.7 & 28.6 \\
\hline Somewhat Committed & 30 & 21.4 & 50.0 \\
\hline Committed & 51 & 36.4 & 86.4 \\
\hline Very Committed & 19 & 13.6 & 100.0 \\
\hline Total & 140 & 100.0 & \\
\hline
\end{tabular}

Source: Survey Data, 2009. $\mathrm{n}=140$

Table 14. Respondents' Level of Willingness to Submit to the PAS

\begin{tabular}{|l|c|c|c|}
\hline Responses & Frequency & Percentage & Cum.\% \\
\hline Very Unwilling & 11 & 7.9 & 7.9 \\
\hline Unwilling & 20 & 14.3 & 22.1 \\
\hline Somewhat Willing & 29 & 20.7 & 42.9 \\
\hline Willing & 58 & 41.4 & 84.3 \\
\hline Very Willing & 22 & 15.7 & 100.0 \\
\hline Total & 140 & 100.0 & \\
\hline
\end{tabular}

Source: Survey Data, $2009 . \quad \mathrm{n}=140$ 